\begin{tabular}{|l|c|c|c|c|c|}
\hline J. Tek. Ling & Vol. 13 & No. 1 & Hal. 13 - 23 & Jakarta, Januari 2012 & ISSN 1441-318X \\
\hline
\end{tabular}

\title{
ANALISIS MDS (MULTI DIMENSIONAL SCALLING) UNTUK KEBERLANJUTAN PENGELOLAAN AIR LINTAS WILAYAH Studi Kasus DKI Jakarta
}

\author{
Samsul Bakeri , M.Yanuar J. P. , Etty Riani , dan Surjono H. Sutjahjo \\ Dosen Pasca Sarjana PSL, Staf Pengajar di Teknik Sipil dan Lingkungan IPB. \\ Dosen Pasca Sarjana PSL, Staf Pengajar di Fakultas Perikanan dan Kelautan IPB. \\ Dosen Pasca Sarjana PSL, Guru Besar Fakultas Pertanian IPB.
}

\begin{abstract}
Abstrak
Jakarta merupakan ibukota Indonesia dan sebagai kota besar dengan jumlah penduduk 9.588.198 orang pada tahun 2010 (BPS, Juli, 2010). Saat ini Jakarta perlu air bersih sebanyak $524.953 .840 \mathrm{~m}^{3}$ untuk domestik dan non domestik $212.606 .350 \mathrm{~m}^{3}$ atau total $737.560 .145,20 \mathrm{~m}^{3}$. Kapasitas produksi dari PAM Jaya pada tahun 2009 sekitar 509.431.934 m3/tahun. PAM Jaya saat ini hanya mampu memenuhi sekitar 69,07\% dari total kebutuhan DKI Jakarta. Untuk memenuhi air bersih, Jakarta membutuhkan air tambahan dari provinsi lain dan $80 \%$ supply untuk Jakarta berasal dari Citarum (Jawa Barat) dan Cisadane (Tangerang-Banten) dan lainnya. Penelitian ini dilakukan selama 13 bulan mulai Juni 2010 sampai Juli 2011. Penelitian ini bertujuan untuk mengidentifikasi penyediaan (supply) dan permintaan air bersih serta mengidentifikasi kebijakan keluar tentang pemenuhan air bersih lintas wilayah atau kabupaten dan membuat model pemenuhan kebutuhan air antar wilayah secara berkelanjutan. Metodologi analisisnya menggunakan Multi Scalling Dimensional (MDS) untuk analisis keberlanjutan air bersih untuk pemenuhan di Jakarta. Pemerintah memiliki peran sentral dalam memenuhi kebutuhan air bersih, pemenuhan air bersih perlu memahami lebih lanjut tentang supply dan permintaan air. Masalah banjir masih sering terjadi. Di dalam pemenuhan air bersih secara berkelanjutan, nilai dimensi ekonomi $(69,17)$ dimensi hukum dan kelembagaan $(68,24)$, dimensi prasarana dan tecnology $(61,45)$, tetapi dimensi ecology tidak berkelanjutan dengan skor (48,75).
\end{abstract}

kata kunci: air bersih, lintas wilayah, pemenuhan,keberlanjutan.

\begin{abstract}
Jakarta is the capital of Indonesia and as a big city with 9.588 .198 people in 2010 (BPS, July, 2010). Jakarta needs clean water 524.953.840 for domestic and non domestic 212.606.350 $\mathrm{m}^{3}$ or the total $737.560 .145,20 \mathrm{~m}^{3}$. PAM Jaya production capacity in 2009 is about $509.431 .934 \mathrm{~m}^{3} /$ year. PAM Jaya capacity is about $69,07 \%$ of the total needs DKI Jakarta. To fulfil the clean water, Jakarta needs water supply from the other provinces and $80 \%$ water supply for Jakarta is from Citarum (West Java) and Cisadane (Tangerang-Banten) and others. A research has been done within 13 months started from 2010 June to 2011 July. The research is aimed to identify the supply and demand of clean water and identify the exiting policy about fulfilment the clean water cross boundaries or district and to make the model of fulfilment the clean water cross boundaries with sustainable. The methodology analysis is Multi Dimensional Scalling (MDS) methodology to analysis sustainablity of fulfilment clean water of Jakarta. The goverment has a central role to fulfill the needs of clean water, fulfilment clean water
\end{abstract}


needs to understand more about supply and demand of water. The problem is the flood has often occured. The sustainable of fulfilment clean water is economi dimensional $(69,17)$ dimensional of law and institution $(68,24)$, dimensional of infrastructur and tecnology $(61,45)$, but dimensional of ecology is not sustainable with the score $(48,75)$.

key words: Clean Water, Cross Boundaries, Fulfilment, Sustainable.

\section{PENDAHULUAN}

\subsection{Latar Belakang}

DKI Jakarta sebagai pusat pemerintahan dan pusat perekonomian Indonesia, membutuhkan air bersih yang sangat besar dan meningkat meningkat terus seiring dengan peningkatan jumlah penduduk. Kebutuhan air bersih bagi penduduk dan industri, memperlihatkan bahwa kebutuhan air baku untuk air minum dan industri akan meningkat pesat hingga tahun 2025 Menurut ${ }^{1}$ yang dimaksud kebutuhan air adalah kebutuhan air yang digunakan untuk menunjang segala kegiatan manusia, meliputi air bersih domestik dan non domestik, air irigasi baik pertanian maupun perikanan, dan air untuk penggelontoran kota. Menurut ${ }^{2}$, keperluan air bersih orang di Indonesia yang tinggal di kota setiap orang per hari adalah 150 liter. Hal tersebut sesuai dengan patokan yang diberikan oleh Departemen Pekerjaan Umum Cq Direktorat Jenderal Cipta Karya yang memberikan angka perkiraan kebutuhan air bersih per orang adalah 150 liter per hari per orang pada tahun 2010.

Kebutuhan air domestik sangat ditentukan oleh jumlah penduduk, dan konsumsi perkapita. Kecenderungan populasi dan sejarah populasi dipakai sebagai dasar perhitungan kebutuhan air domestik terutama penentuan kecenderungan laju pertumbuhan penduduk (Growth Rate Trends). Estimasi populasi untuk masa datang merupakan salah satu parameter utama dalam penentuan kebutuhan air domestik. Laju pertumbuhan juga menjadi parameter yang dipakai untuk analisis1).

Kebutuhan air bersih untuk masyarakat Jakarta pada tahun 2010, baik kebutuhan domestik maupun non domestik sebesar $740.482 .453 \mathrm{~m}^{3}$, sedangkan produksi air bersih PAM Jaya sebesar 509.431.934 m3. Terdapat gap antara kebutuhan air bersih dengan kapasitas produksi air bersih PAM Jaya sebesar kurang lebih 280 juta m3 dan gap tersebut dipernuhi dari air tanah. Sedangkan kondisi air tanah dangkal sebagian besar sudah tercemar bakteri coliform dan detergen ${ }^{3)}$.

Untuk itu PAM JAYA harus berupaya memenuhi kebutuhan air bersih di kota Jakarta yang berkualitas baik dengan harga yang terjangkau serta memberikan kontribusi pada pendapatan daerah. Hal ini sesuai dengan harapan MDG's 2015 di sektor air bersih, yang harus mencoba meminimalkan jumlah penduduk yang tidak mempunyai akses terhadap air bersih yang sehat dan sanitasi dasar.Dalam menjalankan fungsinya, PAM JAYA tidak boleh hanya berbasis komersial, namun juga harus berbasis pada misi sosial dengan sangat memperhatikan aspek lingkungan.

Diperlukan suatu kebijakan yang tepat dalam pengelolaan air lintas wilayah secara berkelanjut dalam rangka memenuhi kebutuhan air bersih DKI Jakarta. Kebijakan seringkali tidak efektif akibat tidak cermat dalam merumuskan masalah. Kebijakan (policy) adalah solusi atas suatu masalah Kebijakan sebagai obat seringkali tidak manjur bahkan mematikan, akibat diagnosa masalah atau penyakitnya keliru ${ }^{4}$. Kebijakan pengelolaan air bersih yang ada saat ini, relatif bersifat parsial, belum holistik dan 
belum lintas sektor dan lintas wilayah.

Kondisi ini semakin diperparah dengan adanya Undang-undang Nomor No. 32 Tahun 2004 tentang otonomi daerah, yang akhirnya cenderung relatif mempertahankan egonya masing-masing. Hal ini mengakibatkan kondisi lingkungan terkait kualitas air sungai kurang diperhatikan, karena merasa bukan menjadi tanggung jawab dari daerah tersebut Sedangkan kuantitas dan kualitas air yang dikelola oleh PAM JAYA sangat tergantung pada daerah lain yang ada dalam satu daerah aliran sungai, misalnya DAS Citarum, namun hingga saat ini kebijakan yang ada belum mendukung ke arah tersebut. Menurut(5), Bab III pasal 10 ayat (3): urusan pemerintah yang menjadi urusan Pemerintah sebagaimana dimaksud pada ayat (1) meliputi: a. Politik luar negeri; b. Pertahanan; c. Keamanan; d. Yustisi; e. Moneter dan fiskal nasional; dan f. Agama. Dalam6) pasal 26 (ayat 1) dinyatakan bahwa: pendayagunaan sumber daya air dilakukan melalui kegiatan penatagunaan, penyediaan, penggunaan, pengembangan, dan pengusahaan sumber daya air dengan mengacu pada pola pengelolaan sumber daya air yang ditetapkan pada setiap wilayah sungai.

Berdasarkan hal tersebut, PAM JAYA dan Pemda DKI Jakarta dalam pengelolaan air baku untuk air bersih harus memperhatikan aspek sosial, ekonomi dan ekologi, secara bersamaan (terintegrasi) dan berkelanjutan. Oleh karena itu, pengelolaan air bersih harus dilakukan secara terpadu antar wilayah dalam DAS karena kebutuhan air baku untuk air bersih DKI Jakarta 70\%-80\% disuplai dari luar provinsi yaitu Waduk Jatiluhur dan Tangerang. Saat ini implementasi kebijakan yang berkaitan dengan air masih minim serta belum terdapat kebijakan yang bersifat holistik dengan pendekatan ekologis serta belum terpadunya antara kuantitas dan kualitas air. Oleh karenanya perlu dibuat model pengelolaan air bersih lintas wilayah yang berkelanjutan.

\subsection{Tujuan}

Penelitian bertujuan untuk mendapatkan model pengelolaan air lintas wilayah berkelanjutan pada era otonomi daerah.

\section{METODOLOGI}

\subsection{Tempat dan Waktu Penelitian}

Penelitian dilakukan di wilayah DKI dan wilayah hulunya, yaitu Daerah Aliran Sungai (DAS) yang menjadi sumber air baku untuk DKI Jakarta. Penelitian dilakukan dari Juli 2010 sampai dengan Juli 2011.

\subsection{Sampling dan Analisis Sample}

Pada penelitian ini dilakukan pengumpulan data primer dengan cara survei lapangan, wawancara dan pengisian kuesioner. Data sekunder diperoleh dari instansi terkait seperti PAM Jaya, Perum Otorita Jatiluhur II, serta Kementrian Pekerjaan Umum. Pada wawancara mendalam, responden dipilih dari stakeholder terpilih dari pemerintah dan para pakar. Pemilihan para pakar dilakukan secara sengaja (proposive sampling).

Dalam penelitian ini, salah satu metode yang digunakan adalah analisis multi dimensional scalling (MDS) dengan tujuan untuk melihat status keberlanjutan pengelolaan lintas wilayah untuk pemenuhan air bersih DKI Jakarta.

\section{HASIL DAN PEMBAHASAN}

Pembangunan berkelanjutan memiliki tiga pilar, yaitu pilar ekonomi, ekologi dan sosial. Pilar ekonomi menekankan pada perolehan pendapatan yang berbasiskan penggunaan sumber daya yang efisien. Pendekatan ekologi menekankan pada pentingnya perlindungan keanekaragaman hayati yang akan memberikan konstribusi pada keseimbangan ekosistem dunia. 
Sedangkan pendekatan sosial menekankan pada pemeliharaan kestabilan sistem sosial budaya, meliputi penghindaran konflik keadilan, baik antar generasi masa kini dengan generasi mendatang. Pembangunan yang berkelanjutan menggabungkan tiga bidang penting yaitu lingkungan, sosial dan ekonomi ke dalam sebuah perspektif tunggal yang terpadu.

Menurut ${ }^{7)}$ perlindungan dan pelestarian sumber air dilaksanakan secara vegetatif atau sipil teknis melalui pendekatan soial, ekonomi dan budaya. Perlindungan secara vegetatif, dilakukan melalui penanaman pepohonan atau tanaman yang sesuai pada daerah tangkapan air atau daerah sempadan sumber air. Sedangkan cara sipil teknis, dilakukan melalui rekayasa teknis, seperti pembangunan penahan sedimen, pembuatan teras (sengkedan) dan penguatan tebing sumber air. Berdasarlam sosial, dimensi infrastruktur dan teknologi serta dimensi hukum dan kelembagaan.

\subsection{Dimensi Ekologi}

Pada dimensi ekologi berdasarkan diskusi para pakar ditetapkan beberapa atribut antara lain ketersediaan sumber air bersih, sanitasi lingkungan, pemenuhan ruang terbuka hijau, kejadian kekeringan, kejadian banjir, kontaminasi mikroba/ zat berbahaya. Analisa status keberlanjutan terhadap dimensi ekologi, diperoleh nilai indeks keberlanjutan 48,75. Nilai indeks dimensi ekologi di bawah nilai indeks keberkelanjutannya. Oleh karena itu, maka dimensi ekologi di lokasi penelitian, termasuk kurang berlanjut (Nilai indeks < 50 ), hal tersebut sebagaimana nampak pada Gambar 1 berikut ini:

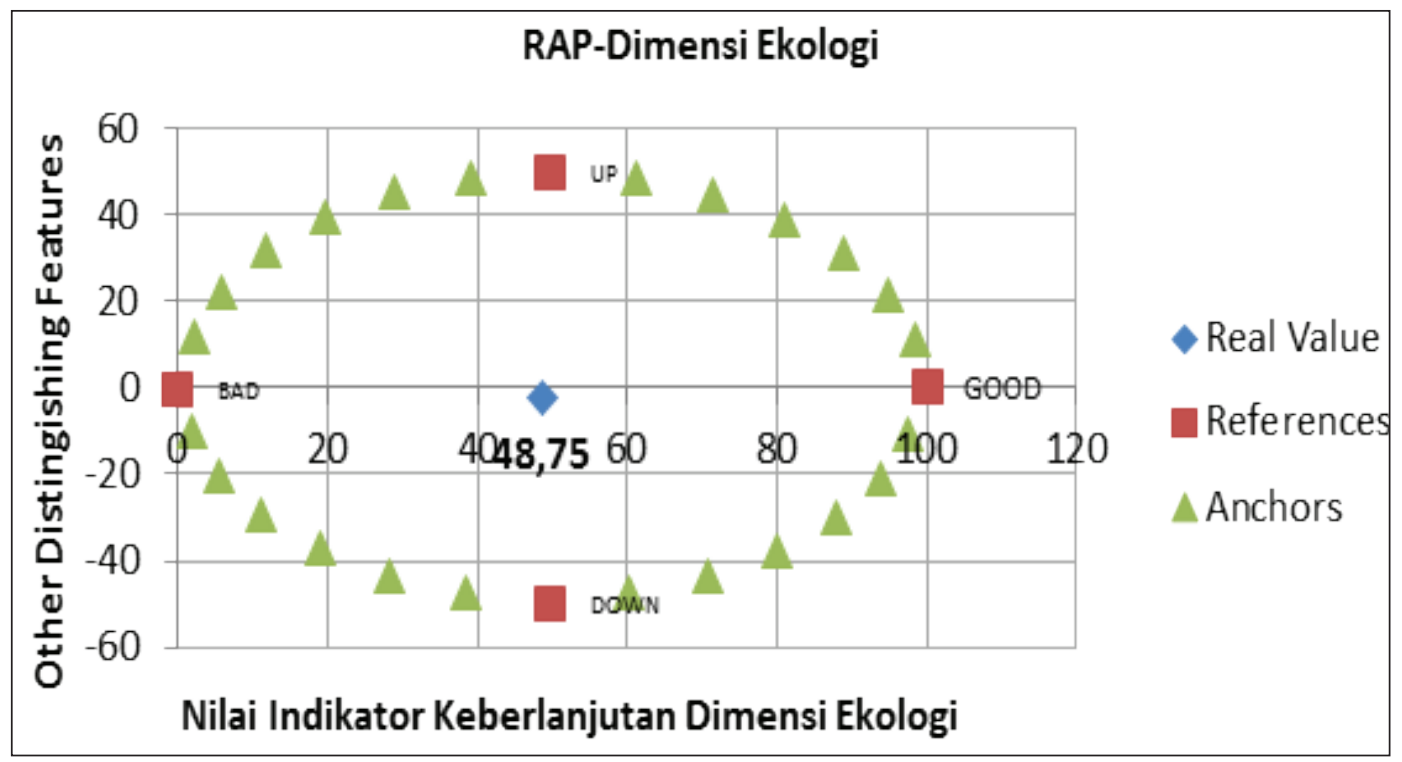

Gambar 1: Indeks keberlanjutan dimensi ekologi.

hal tersebut di atas dan berdasarkan hasil diskusi dengan para pakar, untuk melihat status keberlanjutan dalam pengelolaan air lintas wilayah ditetapkan 5 dimensi yaitu dimensi ekologi, dimensi ekonomi, dismensi
Adapun peran masing-masing aspek pada atribut ekologi yang dianalisa dengan analisa leverage yang bertujuan untuk melihat atribut yang sensitif dalam memberikan kontribusi terhadap keberlanjutan dimensi 
ekologisnya dapat dilihat pada Gambar2.

Pada Gambar 2 ditunjukkan bahwa atribut frekuensi kejadian kekeringan, kejadian banjir dan ruang terbuka hijau merupakan atribut yang sensitif dalam pengelolaan air lintas wilayah. Kejadian kekeringan mengakibatkan debit air di waduk Jatiluhur menurun dratis sehingga menganggu kelancaran pasokan air baku untuk air bersih, sedangkan pada musim hujan air berlebihan bahkan banjir. Pada musim banjir air keruh dan jika tidak terkendali mengakibatkan jebolnhya tanggul sungai seperti yang pernah terjadi di Kalimalang. Sedangkan terkait dengan kualitas air seperti pencemaran dan mikroba memiliki nilai yang sedang artinya tidak begitu sensitif dalam pengelolaan air bersih namun tetap harus diperhatikan. proses pengolahan yang memenuhi syarat kesehatan dan dapat langsung diminum. Pasal 3 ayat (1) Air minum aman bagi kesehatan apabila memenuhi persyaratan fisika, mikrobiologis, kimiawi dan radioaktif yang dimuat dalam parameter wajib dan parameter tambahan. Pasal 3 ayat (2) parameter wajib sebagaimana dimaksud pada ayat (1) merupakan persyaratan kualitas air minum yang wajib diikuti dan ditaati oleh seluruh penyelenggara air minum.

Pengawasan kualitas air bertujuan untuk mencegah penurunan kualitas dan penggunaan air yang dapat mengganggu dan membahayakan kesehatan.Menurut ${ }^{9}$ ) mengatakan air ditemukan berwarna dan berbau, maka harus dicek penyebab timbulnya wanda dan bau. Untuk menjamin

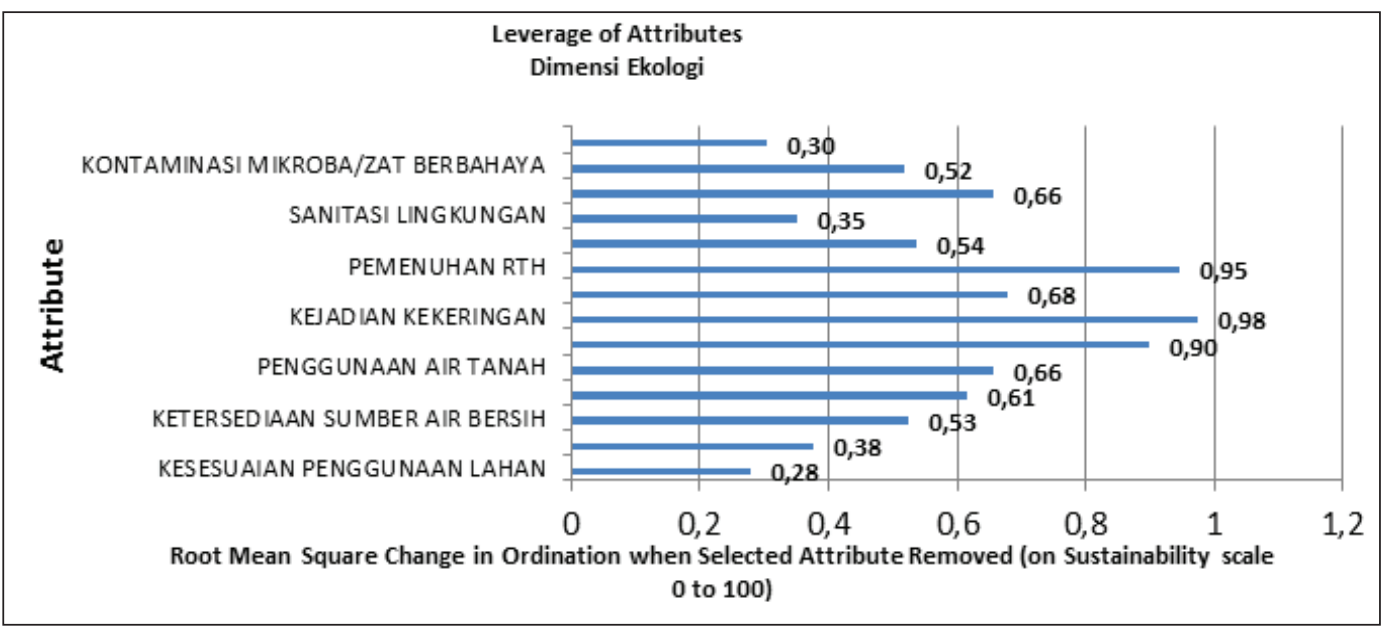

Gambar 2. Peran masing-masing atribut aspek ekologi.

Kualitas air bersih dari PAM Jaya sebenarnya tergantung dari kualitas air baku dan teknologi pengolahan di IPA PAM Jaya. Menurut ${ }^{10)}$ tentang Pengelolaan Kualitas Air dan Pengendalian Pencemaran, Pasal 8 ayat (1) Klasifikasi mutu air ditetapkan menjadi 4 (empat) kelas, air kelas satu, air kelas dua, air kelas tiga dan air kelas empat. Menurut8), tentang Persyaratan Kualitas Air Minum, Pasal 1 ayat (1) air minum adalah air yang melalui proses pengolahan atau tanpa kualitas air tersebut dapat digunakan sumber air, harus dilakukan uji bakteriologis di laboratorium. Padatan tersuspensi total (Total Suspended Solid atau TSS) adalah bahan-bahan tersuspensi (diameter $>1$ $\mu \mathrm{m})$ yang tertahan pada saringan millipore dengan diameter pori $0,45 \mu \mathrm{m}$.

Untuk Ruang Terbuka Hijau dalam artian penyelenggaraan konservasi baik di hulu dan dihilir memiliki nilai yang sangat sensitif, maka hal tersebut perlu diperhaktikan dan 
dilaksanakan dengan baik agar pengelolaan air lintas wilayah. Konservasi yang efektif biasanya meliputi suatu paket langkah pengendalian kebocoran, penggunaan peralatan untuk penghematan air, tarif yang berdaya mencegah pemborosan, dan kampanye untuk mendorong konsumen lebih sadar terhadap akibat penggunaaan air yang boros.

\subsection{Dimensi Ekonomi}

Nilai indeks keberlanjutan dimensi ekonomi sebesar 69,17. Nilai indeks keberlanjutan dimensi ekonomi mengandung arti bahwa dimensi ekonomi pada pemenuhan air bersih lintas wilayah berkelanjutan masuk pada kategori cukup berkelanjutan. Kondisi ini memperlihatkan bahwa pengelolaan air bersih di Jakarta mendatangkan keuntungan bagi pengelolanya. Penyediaan air bersih di DKI Jakarta dilaksanakan oleh PAM Jaya yang merupakan kepanjangan tangan dari pemerintah. PAM Jaya juga mengandeng mitranya yaitu PT. PALYJA dan PT. AETRA. Menurut11) tentang Pengembangan Sistem Penyediaan Air Minum (SPAM) menyatakan bahwa penyediaan air bersih dan air minum bukan lagi menjadi monopoli pemerintah atau BUMN/ BUMD saja, tetapi dapat diselenggarakan oleh koperasi, badan usaha swasta dan masyarakat. Hal ini berarti membuka peluang bagi swasta untuk lebih efisien dalam menekan biaya sehingga harga jual menjad lebih rendah. Tetapi, perlu di waspasai bahwa kegiatan eksploitasi air yang berlebihan dan hanya mementingkan faktor ekonomi akan merusak ekosistem.

Berdasarkan hasil diskusi dengan para pakar atribut-atribut terkait dimensi ekonomi ditetapkan antara lain; 1) presentase penduduk miskin, 2) pendapatan masyarakat perkapita, 3) pendapatan daerah, 4) iklim investasi, 5) penyerapan tenaga kerja, 6) besarnya subsidi air bersih, 7) retribusi air bersih, 8) perkembangan sektor informal, 9) biaya pengelolaan air dibandingkan nilai jual. Berdasarkan hasil analisisi leverage terdapat dua atribut yang sensitif mempengaruhi besarnya nilai indeks keberlanjutan dimensi ekonomi, yaitu: pendapatan daerah $(3,5)$ dan perubahan mata pencaharian $(3,13)$, hal tersebut nampak pada Gambar 3.

Atribut pendapatan daerah adalah atribut yang paling sensitif pada dimensi ekonomi. Untuk itu atribut ini yang harus diperhatikan, karena atribut ini yang dapat mempengaruhi keberhasilan pengelolaan air lintas wilayah. Isu tentang pendapatan daerah pada era otonomi daerah saat ini memang menjadi suatu isu yang sensitif atau isu penting di daerah. Pendapatan dari pengelolaan air bersih oleh PAM Jaya semestinya cukup besar dimana harga air baku dari PJT 2 sebesar Rp. 161,2 / m3 setelah diolah dan didistribusikan kepada masyarakat dengan harga ratarata Rp.3.500,- s.d. Rp. 5.000,-. Namun tingginya tingkat kebocoran yaitu mencapai angka $40 \%$, bahkan dalam kurun waktu 2003 sampai dengan 2008 mencapai angka 45\% s.d. 50\%. Pada tahun 2003 produksi air bersih PAM Jaya sebesar 497.662.644m3 sedangkan air yang terjual sebesar 274.102.317 terjadi kehilangan air sebesar 44,92\%. Pada tahun 2008 produksi air PAM Jaya sebesar $517.964 .539 \mathrm{~m}^{3}$, air terjual sebesar $258.940 .000 \mathrm{~m}^{3}$, kehilangan air sebesar $50,01 \%$. Kehilangan air yang disebabkan oleh kebocoran, ketidaktepatan pencatatan meteran, pencurian air dan lainlain dalam terminologi air bersih biasanya disebut dengan kebocoran.

Kebocoran air pada sistem suplai air bersih mulai dari WTP sampai pemakai dibedakan menjadi dua yaitu kebocoran fisik dan kebocoran administrasi (PERPAMSI dkk.,1990 dengan elaborasi dan modifikasi, dalam $^{1)}$. Kebocoran berakibat pada tingginya harga air bersih dan sekaligus mengindikasikan bahwa pengelolaan air bersih tidak efisien. Sehingga perlu dilakukan evaluasi agar bisnis ini dapat berjalan dengan sehat dengan tetap memperhatikan harga yang terjangkau dan keseimbangan dengan lingkungan 


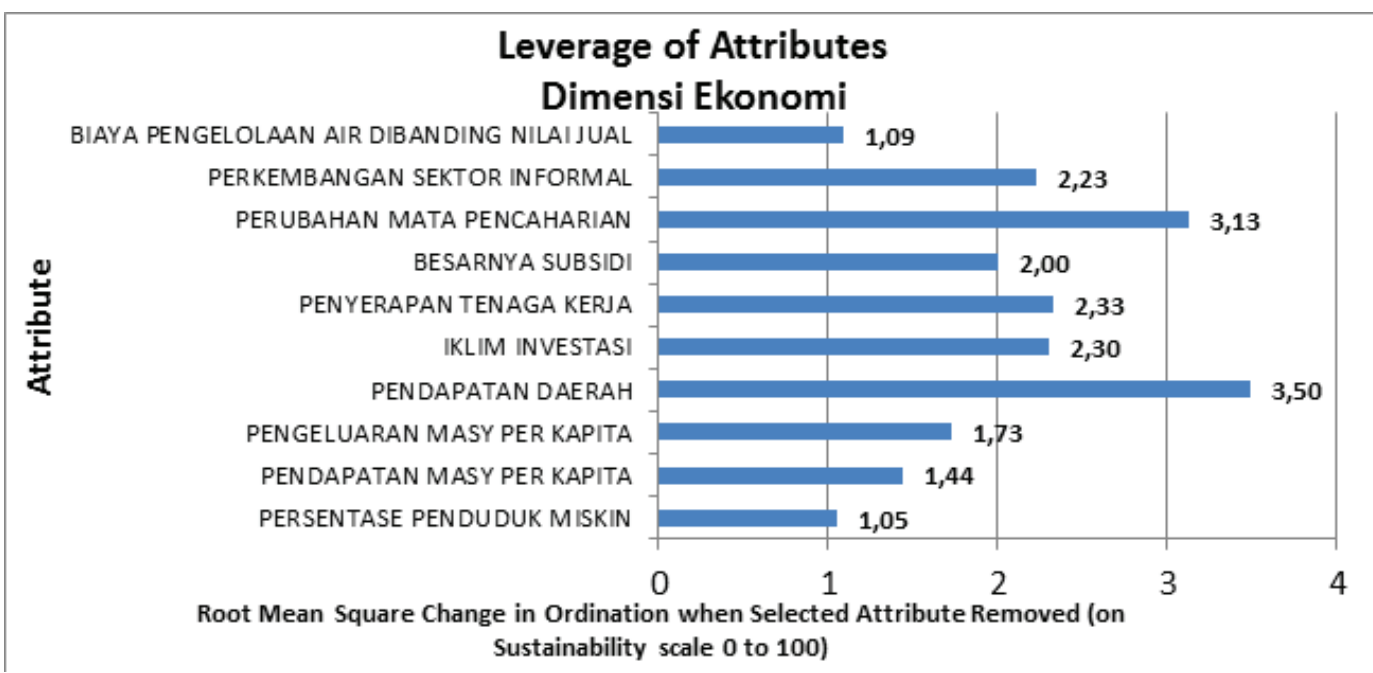

Gambar 3. Nilai indeks keberlanjutan dimensi ekonomi.

\subsection{Dismensi sosial}

Pada dimensi sosial dibagi menjadi 18 atribut antara lain terdiri dari (1) pendidikan masyarakat, (2) pemberdayaan masyarakat, (3) kesehatan masyarakat, (4) pola hidup bersih masyarakat, (5) kepadatan penduduk, (6) perilaku membuang sampah ke sungai, (7) kesadaran lingkungan, (8) pengetahuan lingkungan, (9) partisipasi masyarakat dalam prokasi, (10) partisipasi masyarakat dalam program penghijauan, (11) tingkat pencurian air bersih oleh masyarakat, (12) keluhan masyarakat dalam pelayanan PAM, (13) ketepatan waktu dalam pembayaran rekening air, (14) gangguan kesehatan akibat mengkonsumsi air bersih, (15) jumlah masyarakat yang belum memperoleh pelayanan air bersih, (16) jumlah masyarakat yang mempunyai sarana MCK tidak sehat, (17) persepsi masyarakat terhadap harga air, (18) jumlah penduduk yang tinggl di permukiman kumuh. Namun, demikian peningkatan indeks dimensi sosial dapat dilakukan dengan perbaikan-perbaikan terhadap atribut yang diperkirakan berpengaruh terhadap nilai indeks dimensi sosial

Nilai indeks keberlanjutan dimensi sosial berdasarkan analisis MDS adalah sebesar 56,52 atau di atas 50, sehingga termasuk ke dalam kategori berkelanjutan. Atribut-atribut yang sensitif mempengaruhi indeks keberlanjutan dimensi sosial adalah 1) tingkat ketepatan pembayaran $(2,04)$, tingkat gangguan masyarakat $(1,86)$, tingkat partisipasi masyarakat dalam program air bersih $(1,72)$. Hal tersebut memberikan makna bahwa dalam pengelolaan air lintas wilayah agar memperhatikan ketepatan pembayaran rekening air, tingkat kesehatan masyarakat serta tingkat partisipasi masyarakat dalam program air bersih. Ketiga atribut tersebut sensitif atau penting dalam menentukan keberlanjutan pengelolaan air bersih pada dimensi sosial untuk itu perlu diperhatikan atribut-atribut tersebut (Gambar 4).

\subsection{Dimensi infrastruktur dan teknologi}

Berdasarkan hasil diskusi para pakar atribut dalam dimensi infrastruktur dan teknologi adalah 1) tingkat penguasaan teknologi, 2) teknologi ramah lingkungan, 3) reklamasi lahan, 4) kualitas air bersih yang dihasilkan, 5) pembangunan DAM dan saluran air, 6) dukungan sarana dan prasarana. Hasil analisis MDS pada 


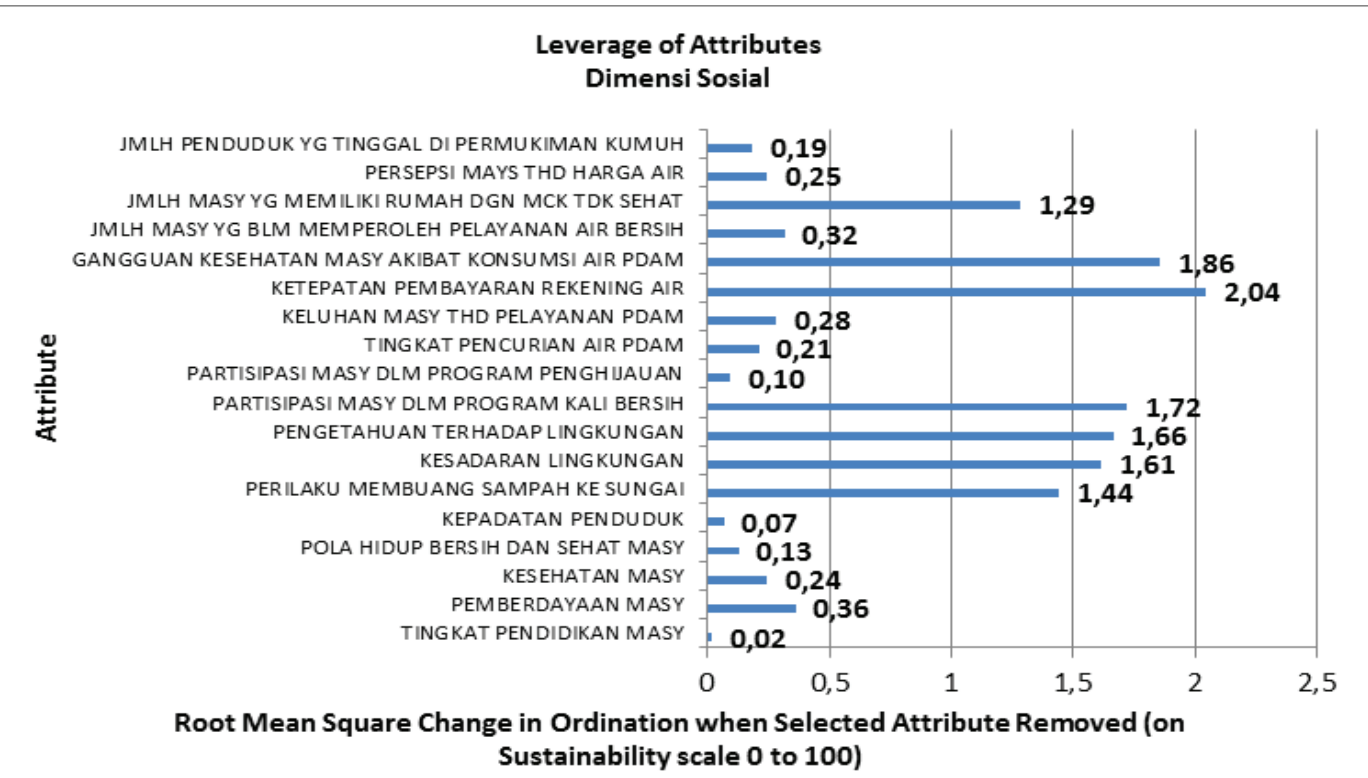

Gambar: 4. Peran masing-masing atribut dimensi sosial.

dimensi infrastruktur dan teknologi terkait pengelolaan air lintas wilayah menunjukkan nilai indeks sebesar 61,45. Nilai tersebut memperlihatkan bahwa keberlanjutan dimensi infrastruktur dan teknologi pada pengelolaan air lintas wilayah pada kategori baik. Terdapat dua atribut yang paling sensitif pada dimensi infrastruktur dan teknologi yaitu atribut dukungan sarana dan prasarana sebesar 5,57 dan atribut tingkat penguasaan teknologi dengan nilai 4,76. Dari fakta di lapangan menunjukkan bahwa memang dukungan infrastruktur untuk pengelolaan air cukup bagus. Kementrian Pekerjaan Umum sedang merencanakan untuk membangun saluran bawah tanah yang mengalirkan air dari Citarum ke Jakarta dan juga sedang melakukan kajian studi kelayakan tentang pembangunan saluran air bawah tanah dari Provinsi Banten ke DKI Jakarta.

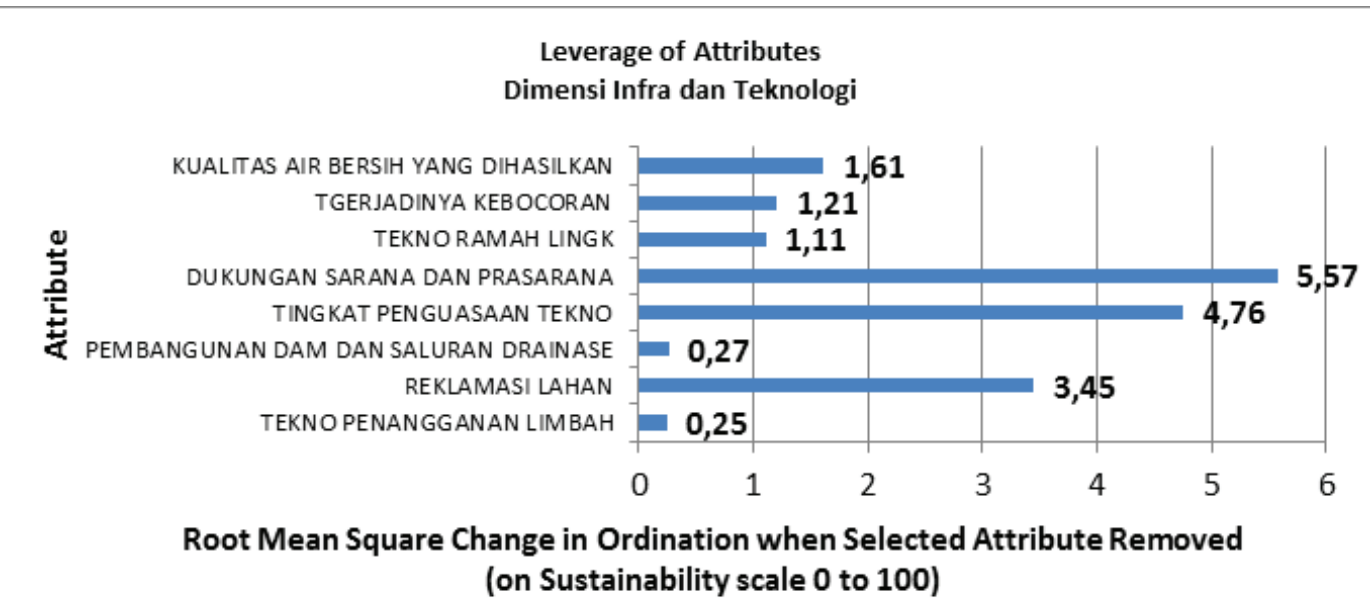

Gambar 5: Peran masing-masing atribut dimensi infrastruktur dan teknologi. 


\subsection{Dimensi hukum dan kelembagaan}

Atribut dimensi hukum dan kelembagaan terdiri dari (1) ketersediaan perangkat hukum, (2) sinkronisasi kebijakan pusat, (3) kelembagaan pengelola, (4) keberadaan lembaga keuangan, (5) ketersediaan lembaga sosial, (6) ketersediaan organisasi masyarakat, (7) ketersediaan pengawasan hukum, (8) ketersediaan penegak hukum, (9) penyuluhan hukum pengelolaan sumber daya alam dan lingkungan, (10) transportasi dalam kebijakan, (11) intensitas pemanfaatan yang melanggar hukum. Hasil analisis terhadap dimensi hukum dan kelembagaan mendapatkan hasil lembaga sosial $(3,82)$ dan keberadaan lembaga keuangan $(3,73)$ serta kapasitas kelembagaan pengelola $(3,23)$. Untuk lebih jelasnya peran masing-masing atribut dari dimensi hukum dan kelembagaan dapat dilihat pada Gambar 6.

Atribut yang memiliki nilai tinggi atau sensitif yaitu atribut ketersediaan lembaga sosial, keberadaan lembaga keuangan dan kelembagaan pengelola air bersih. Ketiga atribut tersebut perlu diperhatikan dan diwaspadai karena atribut tersebut merupakan atribut penting dan menentukan keberhasilan pengelolaan air lintas wilayah.

Dari kelima dimensi yaitu dimensi ekonomi, dimensi ekologi, dimensi sosial,

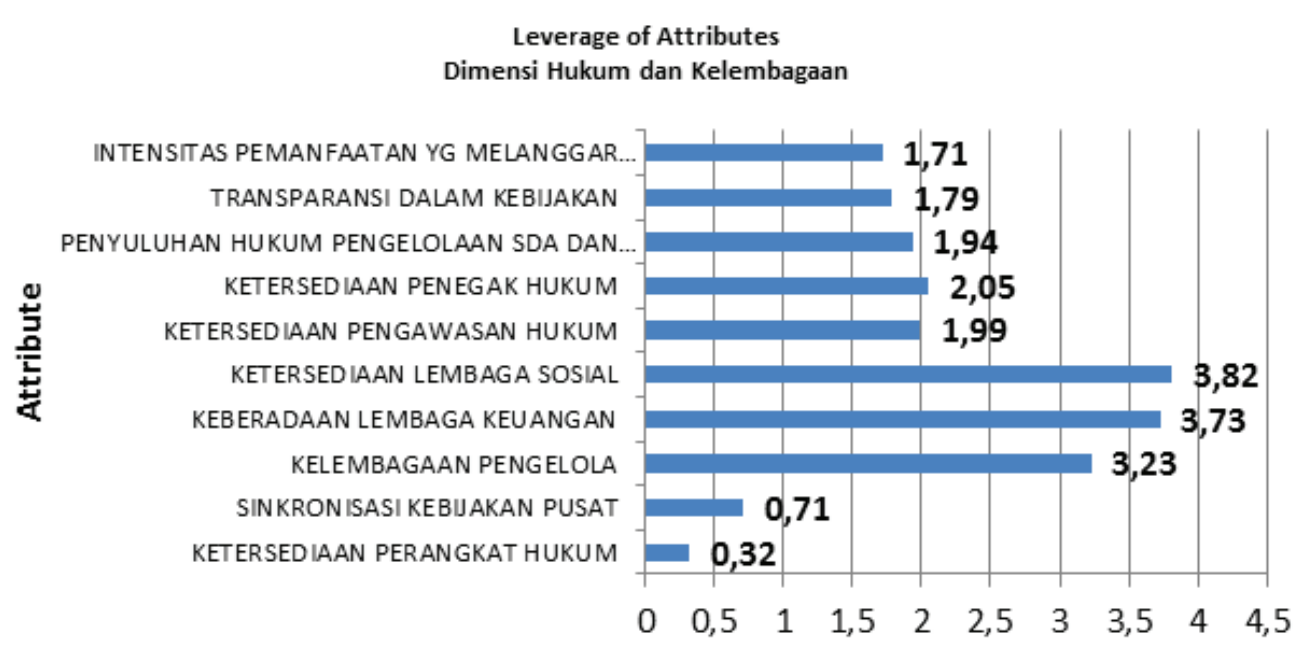

Root Mean Square Change in Ordination when Selected Attribute Removed (on Sustainability scale 0 to 100 )

Gambar 6: Peran masing-masing atribut dimensi hukum dan kelembagaan.

bahwa nilai indeks keberlanjutan dimensi hukum dan kelembagaan sebesar 68,24. Dimensi hukum dan kelembagaan pada pengelolaan air bersih lintas wilayah berkelanjutan (studi kasus DKI Jakarta ) termasuk ke dalam kategori berkelanjutan. Berdasarkan analisis leverage terdapat tiga atribut yang sensitif mempengaruhi nilai indeks keberlanjutan dimensi hukum dan kelembagaan, yaitu: Ketersediaan dimensi infrastruktur dan teknologi dapat diketahui dimensi ekonomi yang memiliki skor atau paling tinggi tingkat kebelanjutannya lihat Gambar 7. Diagram layang-layang yang digambarkan pada Gambar 7 menunjukkan bahwa dimensi ekologi belum menjadi prioritas utama. Fakta di lapangan menunjukkan bahwa harga air saat ini yang menjadi perhatian dimensi ekonomi dan nilai tambah dari pengelolaan 
air dinikmati oleh lembaga yang ditunjuk oleh pemerintah daerah sebagai lembaga pengelola.

Gambar 7 menunjukkan bahwa tingkat keberlanjutan yang paling baik adalah dimensi ekonomi disusul kemudian dimensi hukum dan kelembagaan, dimensi infrastruktur dan teknologi serta dimensi sosial, sedangkan dimensi ekologi memiliki nilai terendah yaitu < 50 yaitu sebesar $(48,75)$. di waduk Jatiluhur dan sekitar DAS mengakibatkan volume air baku terancam kestabilannya. Jika musim banjir, volume air berlebihan di waduk Jatiluhur, namun keruh. Hal itu mengancam akan pengelolaan air bersih dalam memenuhi kriteria kualitas, kuantitas dan kontinuitas. Seringnya kejadian banjir dan kekeringan akibat tidak dipenuhi ruang terbuka hijau baik sebagai resapan air di hulu maupun di hilir.

- Dimensi sosial memiliki indeks

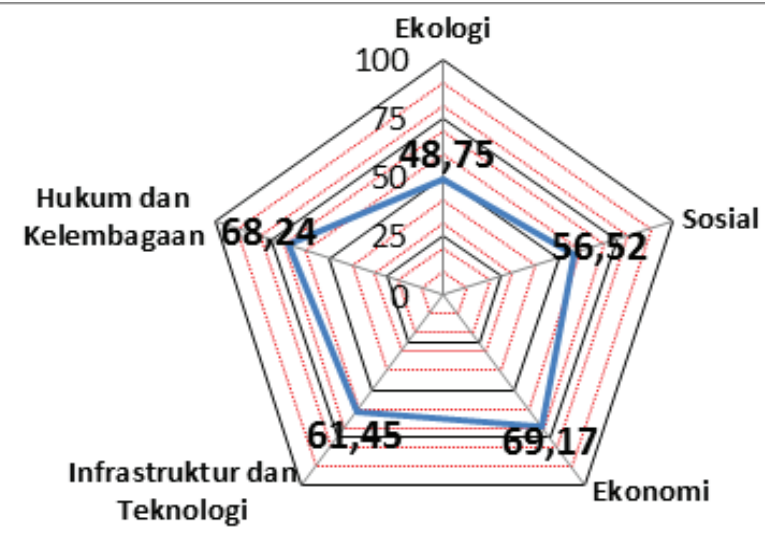

Gambar 7. Diagram layang layang

\section{KESIMPULAN DAN SARAN}

\subsection{Kesimpulan}

- Berdasarkan analisis MDS menunjukkan bahwa pengelolaan air lintas wilayah studi kasus pemenuhan air bersih untuk DKI Jakarta, terdapat lima dimensi dengan tingkat keberlanjutan untuk masingmasing dimensi sebagai berikut dimensi ekonomi $(69,17)$, dimensi hukum dan kelembagaan $(68,24)$, dimensi infrastruktur dan teknologi $(61,45)$, dimensi sosial $(56,52)$ dan dimensi ekologi dengan nilai $<50$ yaitu $(48,75)$.

- Dimensi ekologi memiliki tingkat keberlanjutan yang paling rendah $(48,75)$ dengan atribut yang sensitif yaitu 1) kejadian kekeringan, 2) pemenuhan $\mathrm{RTH}$, serta 3) seringnya terjadi banjir.

- Seringnya kejadian kekeringan keberlanjutan sebesar 56,52. Dimensi ini juga tergolong kritis artinya nilai keberlanjutannya mendekati nilai 60 dan atribut yang sensitif yaitu ketaatan dalam pembayaran rekening. Ketaatan masyarakat dalam membanyar rekening air akan menjadi kekecewaan jika tidak diimbangi dengan pelayanan yang baik misalnya terpenuhinya kualitas dan kuantitas serta kontinuitas air bersih.

\subsection{Saran}

- Pengelolaan air lintas wilayah berkelanjutan harus memperhatikan dan mengintegrasikan atribut-atribut sensitif, yakni keberadaan ruang terbuka hijau (RTH), ketepatan pembayaran rekening air, pendapatan daerah, dukungan sarana dan prasarana, ketersediaan lembaga sosial dan lembaga keuangan serta lembaga pengelola air bersih. 
- Perlu dilakukan perbaikan terhadap pemenuhan Ruang Terbuka Hijau baik di hulu DAS Citarum maupun di hilir Jakarta dan sekitarnya. Pemenuhan RTH dan konservasi sumber daya alam dan konservasi sumber daya air di hulu DAS Citarum akan menjaga kestabilan sumber air baku untuk air bersih baik segi kualitas, kuantitas maupun kontinyuitas.

\section{DAFTAR PUSTAKA}

1. Kodoatie dan Syarif, 2008, Tata Ruang Air. Andi. Yogyakarta.

2. Sjarief . 2008. Pengelolaan Sumber Daya Air Terpadu. Andi. Yogyakarta.

3. Sri Widyastuti, Endang. 2003. Hubungan Permukiman Kumuh Dengan Pemenuhan Air Bersih dan Lingkungan Permukiman Sehat (Kasus DKI Jakarta), (disertasi), Bogor: Program Pascasarjana, Institut Pertanian Bogor.

4. Dunn. 2003. Pengantar Analisis Kebijakan Publik, Gajah Mada University Press, Yogyakarta.
5. Undang-Undang Republik Indonesia Nomor 32 Tahun 2004, tentang Pemerintahan Daerah.

6. Undang-Undang Republik Indonesia Nomor 7 tahun 2004 tentang Sumber Daya Air.

7. Sanim, B. 2011. Sumberdaya Air dan Kesejahteraan Publik, Suatu Tinjauan Teoritis dan Kajian Prkatis. IPB Press. Bogor.

8. Peraturan Menteri Kesehatan No. 492/MENKES/PER/IV/2010, tentang Persyaratan Kualitas Air Minum.

9. Effendi. 2003. Telaah Kualitas Air, Bagi Pengelolaan Sumber Daya dan Lingkungan Perairan, Penerbit Kanisius, Yogyakarta.

10. Peraturan Pemerintah Republik Indoensia Nomor 82 Tahun 2001 tentang Pengelolaan Kualitas Air dan Pengendalian Pencemaran Air.

11. Peraturan Pemerintah Republik Indonesia Nomor 16 Tahun 2005 Tentang Pengembangan sistem penyediaan Air minum 